\title{
Plant-derived compounds in clinical trials
}

\section{Arvind Saklani and Samuel K. Kutty}

Department of Natural Products, National Institute of Pharmaceutical Education and Research (NIPER), Sector-67, SAS Nagar 160062, Punjab, India

Plants remain an important source of new drugs, new drug leads and new chemical entities. The plantbased drug discovery resulted mainly in the development of anticancer and anti-infectious agents and continues to contribute to the new leads in clinical trials. A total of 91 plant-derived compounds in clinical trials as of September 2007 are described in this review. A summary of the plant-based drugs launched during 2000-2006 is given.

Plants have been an integral part of the ancient culture of India, China and Egypt as medicine, and their importance even dates back to the Neanderthal period [1]. In the modern world, the finding of cinchona in 17 th century, followed by digitalis, morphine, and so on, and then introduction of synthetic aspirin, a derivative of a plant-based drug, compelled human beings to believe in the wonders of the diverse floristic wealth [2]. A large number of plants used in the traditional medicine have now become a part of the modern world health care system [3]. Natural products offer large structural diversity [4], and modern techniques for separation, structure elucidation, screening and combinatorial synthesis [5-7] have led to revitalization of plant products as sources of new drugs. The introduction of herbals in the form of nutraceuticals and dietary supplements are also changing the plant-based drug market $[8,9]$.

In the recent past, comprehensive reviews have appeared on natural products, including marine products in clinical trials [1014]. This review describes plant-derived compounds, including herbal preparations in clinical trials as on September 2007, by disease area.

\section{The market share of plant drugs}

The global market for plant-derived drugs was worth an estimated $\$ 18$ billion in 2005. BCC expects this figure to grow to nearly \$19 billion in 2006 and more than $\$ 26$ billion by 2011, at an average annual growth rate (AAGR) of $6.6 \%$ between 2006 and 2011 [15]. The U.S. accounts for $50 \%$ of the global plant-derived drug market and is expected to grow faster than other markets at an AAGR of $7.5 \%$ per year vs. $5.3 \%$ [16].

A total of 26 plant-based drugs were approved/launched during 2000-2006, which also include novel molecule-based drugs like Galanthamine $\mathrm{HBr}$ (Reminyl ${ }^{\mathbb{R}}$ ), Miglustat (Zavesca ${ }^{\mathbb{R}}$ ) and Nitisinone (Orfadin ${ }^{\circledR}$ ) (Table 1).

\section{Plant-derived natural products in clinical trials}

For many centuries plants have been the main source of crude drugs used to cure or alleviate human sickness. In today's era of medicine engineering also, plants play an equally important role in drug discovery and development. The plant-derived compounds presently in clinical trials are discussed below for important therapeutic category (Figures 1 and 2).

\section{Infectious and parasitic disease applications}

Infectious and parasitic diseases are the second major cause of death, accounting for 15 million deaths each year worldwide [25]. Unlike antibacterials, which are dominated by antibiotics, plants have produced potential antiviral and antiparasitic drugs [26-28]. The drugs in clinical trials for different infectious and parasitic diseases are described below.

Artemisone/Artemifon (BAY 44-9585) in Phase II: This is a semisynthetic antimalarial derivative of artemisinin that was first isolated from Artemisia annua (Asteraceae), a plant native to China, in 1971. Preclinical and clinical development of BAY 449585 (artemisone) is being done in collaboration with Medicines for Malaria Venture (MMV), Mahidol University, Bangkok and Bayer AG for the treatment of Plasmodium 
Table 1

Drugs approved/launched based on plant natural products during the period of 2000-2006

\begin{tabular}{|c|c|c|c|c|c|}
\hline Year & Generic name & Lead compound & Disease area & Company & Reference \\
\hline 2000 & Exelon (Rivastigmine tartrate) & Physostigmine & $\begin{array}{l}\text { Dementia-Alzheimer's } \\
\text { disease }\end{array}$ & Novartis & $\begin{array}{l}\text { [http://wwww.centerwatch.com/ } \\
\text { patient/drugs/druglist/], [17] }\end{array}$ \\
\hline 2000 & Arteether $\left(\right.$ Artemotil $\left.{ }^{1 /}\right)$ & Artemisinin & Antimalarial & Brocacef & [18] \\
\hline 2000 & Galanthamine $\mathrm{HBr}\left(\operatorname{Reminy} \mathrm{l}^{\mathrm{\Phi}}\right)^{\mathrm{b}}$ & Galanthamine & Alzheimer's disease & Shire (U.K.), Johnson \& Johnson (U.S.) & [18] \\
\hline 2000 & Bexarotene & Retenoic acid derivatives & Cutaneous T cell lymphoma & Ligand Pharmaceuticals & [18] \\
\hline 2000 & L-dopa-methyester (Levomet) & L-Dopa & Parkinson's diseases & Chiesi & [18] \\
\hline 2000 & $\begin{array}{l}\text { Malarone (Atovaquone; } \\
\text { proguanil hydrochloride) }\end{array}$ & Quinine & Antimalarial & GlaxoWellcome & $\begin{array}{l}\text { [http://www.centerwatch.com/ } \\
\text { patient/drugs/druglist/], [17] }\end{array}$ \\
\hline 2000 & Rapacuronium bromide (Raplon) & Tubocurarine & $\begin{array}{l}\text { Neuromuscular blocking } \\
\text { agent/anaesthesia }\end{array}$ & Akzo Nobel (Netherlands) & [18] \\
\hline 2001 & Galanthamine $\mathrm{HBr}\left(\operatorname{Reminy} \mathrm{l}^{\circledR}\right)^{\mathrm{b}}$ & Galanthamine & Dementia-Alzheimer's & Janssen Pharmaceuticals & $\begin{array}{l}\text { [http://www.centerwatch.com/ } \\
\text { patient/drugs/druglist/] }\end{array}$ \\
\hline 2002 & Nitisinone (Orfadin ${ }^{\oplus}$ ) & Leptospermone & Antityrosinaemia & Orphan Pharmaceuticals & $\begin{array}{l}\text { [http://www.centerwatch.com/ } \\
\text { patient/drugs/druglist/], [19] }\end{array}$ \\
\hline 2002 & Tiotropium bromide & Tiotropium & $\begin{array}{l}\text { Chronic obstructive } \\
\text { pulmonary disease }\end{array}$ & Boehringer Ingelheim & [19] \\
\hline 2002 & Avinza (Morphine sulfate) ${ }^{c}$ & Morphine & Pain & Elan & $\begin{array}{l}\text { [http://www.centerwatch.com/ } \\
\text { patient/drugs/druglist/] }\end{array}$ \\
\hline 2003 & Miglustat $\left(\text { Zavesca }^{(B)}\right)^{d}$ & 1-Deoxynojirimycin & Type1 Gaucher disease & Oxford Glycosides/Actelion/Celltech & {$[20-22]$} \\
\hline 2004 & $\begin{array}{l}\text { Spiriva HandiHaler } \\
\text { (Tiotropium bromide) }^{c}\end{array}$ & Tiotropium & $\begin{array}{l}\text { Chronic obstructive } \\
\text { pulmonary disease }\end{array}$ & Boehringer Ingelheim & $\begin{array}{l}\text { [http://www.centerwatch.com/ } \\
\text { patient/drugs/druglist/], [http:// } \\
\text { www.drugs.com/newdrugs/] }\end{array}$ \\
\hline 2004 & Apokyn (apomorphine $\mathrm{HCl})^{c}$ & Apomorphine & Parkinson's diseases & $\begin{array}{l}\text { Mylan Bertek } \\
\text { pharmaceuticals }\end{array}$ & $\begin{array}{l}\text { [http://www.centerwatch.com/ } \\
\text { patient/drugs/druglist/; http:// } \\
\text { www.drugs.com/newdrugs/] }\end{array}$ \\
\hline 2004 & Palladone (hydromorphone) & & Moderate-to-severe pain & Purdue Pharma L.P. & [http://www.drugs.com/newdrugs/] \\
\hline 2004 & $\begin{array}{l}\text { DepoDur (morphine sulfate) } \\
\text { extended release }^{c}\end{array}$ & Morphine & Post-surgical pain relief & $\begin{array}{l}\text { SkyePharma PLC and Endo } \\
\text { Pharmaceuticals }\end{array}$ & [http://www.drugs.com/newdrugs/] \\
\hline 2004 & Belotecan & Campthotecin & Ovarian \& small lung cancer & Chong Kun Dang & [23] \\
\hline 2005 & Tamibarotene (Amnolake) & Retenoic acid derivatives & Acute myelogenous leukaemia & Nippon Shinyaku & [24], http://www.nippon-shinyaku.co.jp/ \\
\hline 2005 & $\begin{array}{l}\text { Abraxane }(\text { paclitaxel } \\
\text { protien-bound particles) }\end{array}$ & Paclitaxel & Breast cancer & $\begin{array}{l}\text { American Pharmaceuticals } \\
\text { Partners, Inc./American Bioscience }\end{array}$ & [http://www.drugs.com/newdrugs/] \\
\hline 2005 & THC:CBD (Sativex)e & $T H C, C B D$ & MS pain & GW Pharma & [24] \\
\hline 2006 & Taxotere (docetaxel) injection ${ }^{f}$ & Docetaxel & $\begin{array}{l}\text { Antineoplastic (head and neck } \\
\text { cancer) and stomach cancer }\end{array}$ & Sanofis-Aventis & [http://www.drugs.com/newdrugs/] \\
\hline 2006 & $\begin{array}{l}\text { Duodote (atropine and } \\
\text { pralidoxine chloride) injection }\end{array}$ & Atropine & $\begin{array}{l}\text { Exposure to organophosphorous } \\
\text { nerve agents (Antidote) }\end{array}$ & $\begin{array}{l}\text { Meridian Medical } \\
\text { Technologies }\end{array}$ & [http://www.drugs.com/newdrugs/] \\
\hline 2006 & Exelon (rivastigmine tartrate) ${ }^{f}$ & Phytostigmine & Dementia-Parkinson's & Novartis & [http://www.drugs.com/newdrugs/] \\
\hline 2006 & Hycamtim (topotecan $\mathrm{HCl}$ ) & Camptothecin & Cervical cancer & GlaxoSmithkline & [http://www.drugs.com/newdrugs/] \\
\hline 2006 & Cesamet (nabilone) & Delta-9-THC & $\begin{array}{l}\text { Chemotherapy nausea } \\
\text { and vomiting }\end{array}$ & Valeant Pharmaceuticals International & [http://www.drugs.com/newdrugs/] \\
\hline 2006 & $\begin{array}{l}\text { Polyphenon E (Veregen) } \\
\text { Ointment }\end{array}$ & $\begin{array}{l}\text { Green tea polyphenol } \\
\text { (catechin) extract }\end{array}$ & Genital and perianal warts & MediGene AG & [http://www.drugs.com/newdrugs/] \\
\hline
\end{tabular}

${ }^{a}$ New formulation (NDDS) and new indications of existing drugs are included.

${ }^{\mathrm{b}}$ Galanthamine (Reminyl ${ }^{\mathbb{B}}$ ) was approved for sale in U.K. and Ireland in 2000 and was approved for sale in U.S. by 2001 November and was launched in January 2002.

New formulation or new salt form of an existing drugs.

dMiglustat (Zavesca) was approved in U.K. in 2002, launched by 2003 by Celltech, and approved in U.S. in 2003.

e Sativex launched in Canada, U.K. and in clinical trials in U.S.

${ }^{\mathrm{f}} \mathrm{New}$ indication of an existing drugs. 


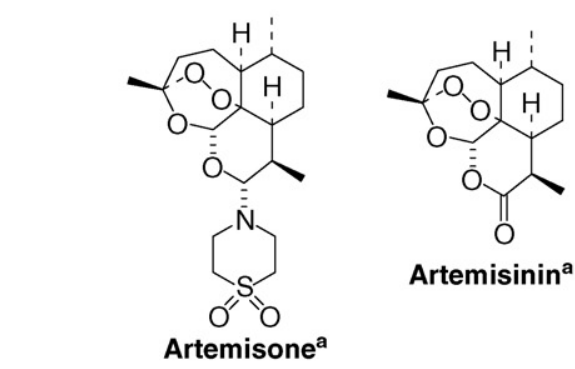<smiles>O=C(/C=C/c1ccc(O)c(O)c1)O[C]1C[C@@](O)(C(=O)O)CC(OC(=O)/C=C/c2ccc(O)c(O)c2)[C@@H]1O</smiles>

3,5-di-O-caffeoylquinic acid ${ }^{\mathrm{a}}$<smiles>CCCc1cc(=O)oc2c3c(c4c(c12)OC(C)(C)C=C4)OC(C)C(C)C3O</smiles>

Calanolide $\mathbf{A}^{\mathrm{a}}$

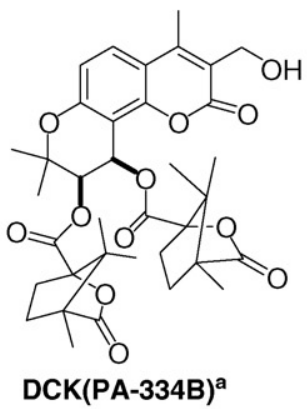<smiles></smiles><smiles>CCCC(=O)C(C)=CPS(C)(=O)=O</smiles>

Castanospermine $^{a} \mathrm{R}=\mathrm{H}$

\section{4-methylumbelliferone ${ }^{a}$}<smiles>CC(C)(C)C(=O)CC(C)(C)C(=O)O</smiles>

Betulinic acid $^{\mathrm{a}} \mathrm{R}=\mathrm{H}$<smiles>COc1cc(CNC(=O)CCCC/C=C/C(C)C)ccc1O</smiles>

Capsaicin $^{\mathrm{b}}$<smiles>CCc1ccccc1NC(=O)Oc1ccc2c(c1)[C@@]1(C)CCN(C)O[C@]1(C)N2C</smiles>

Ganstigmine $^{\text {b }}$<smiles>[R]NC(=O)Oc1ccc2c(c1)[C@@]1(C)CCN(C)[C@H]1N2C</smiles>

Phenserine ${ }^{\mathrm{b}} \mathrm{R}$<smiles>c1ccc(C2CC2)cc1</smiles>

Phytostigmine ${ }^{\mathrm{b}} \mathrm{R}=\mathrm{CH}_{3}$<smiles>CC=C1C2C=C(C)CC1(N=Cc1cc(Cl)cc(OC)c1O)c1ccc(=O)[nH]c12</smiles>

ZT-1 ${ }^{\text {b }}$<smiles>COc1cc(CC(=O)NCCCc2ccc(C)c(C)c2)ccc1OCCN</smiles>

DA-5018<smiles>CN1C(CC(=O)c2ccccc2)CCCC1CC(O)c1ccccc1</smiles>
Lobeline $^{b}$<smiles>CCCCCCC(C)(C)c1cc(O)c2c(c1)OC(C)(C)[C@H]1CC=C(CO)C[C@H]21</smiles>

Dexanabinol $^{\mathrm{b}}$

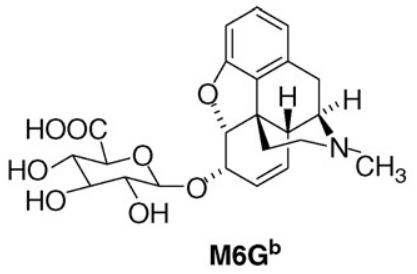<smiles>CCCCCCC(C)(C)c1cc(O)c2c(c1)OC(C)(C)[C@H]1CC=C(C(=O)O)C[C@H]21</smiles>

IP-751<smiles>CCCCCc1cc(O)c2c(c1)OC(C)(C)[C@H]1CC=C(C)C[C@H]21</smiles>

Tetrahydrocannabinol(THC) $)^{\text {b }}$<smiles>CCCCCCCc1cc(O)c([C@H]2CC(C)=CCC2C(C)(C)C)c(O)c1</smiles>

Cannabidiol $^{b}$



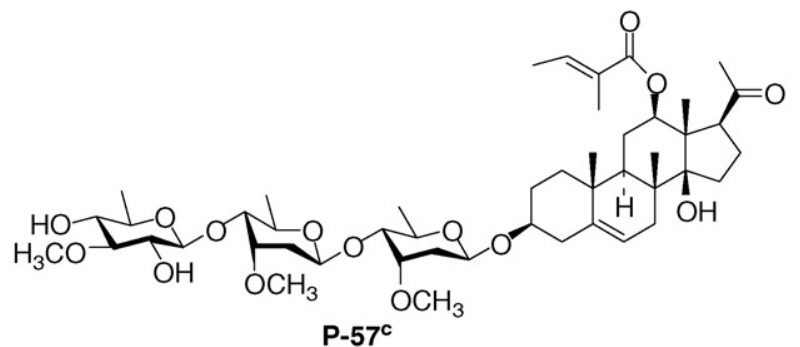

$\overline{\text { Drug Discovery Today }}$

\section{FIGURE 1}

Plant-derived compounds launched in clinical trials. (a) Infectious and parasitic disease application, (b) pain and neurological disease application, (c) cardiovascular and metabolic disease application. 


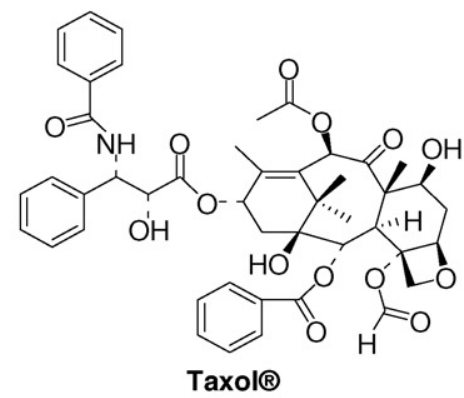<smiles>COc1ccc(-c2ccc(OC)c(OC)c2)cc1OC</smiles>

Camptothecin

Combrestatin<smiles>COc1cc(C2c3cc4c(cc3C(O)C3COC(=O)[C@H]23)OCO4)cc(OC)c1OC</smiles>

Epipodophyllotoxin<smiles>COC(=O)C=C(C)C(C)C</smiles>

Bruceatin

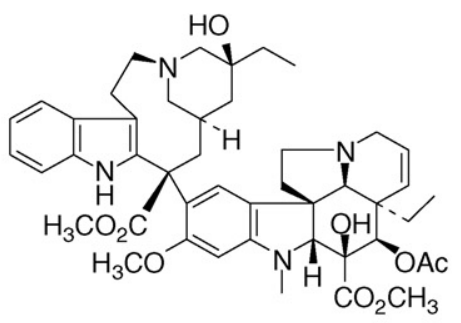

Vinblastine

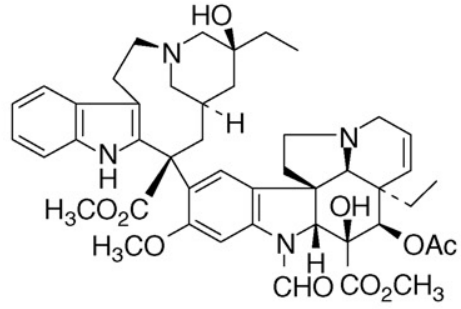

Vincristine<smiles>Cc1ccc2c(=O)c3cccc(CC(=O)O)c3oc2c1C</smiles>

DMXAA<smiles>CN1CC[C@H](c2c(O)cc(O)c3c(=O)cc(-c4ccccc4Cl)oc23)[C@@H](O)C1</smiles>

Flavopiridol

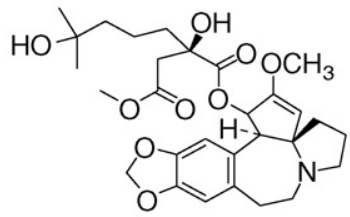

Homoharringtone

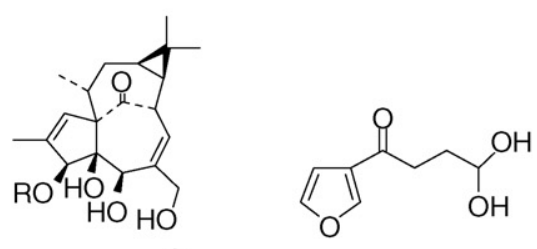

$\begin{aligned} & \text { Ingenyl3- } \\ & \text { angelate }\end{aligned}=$

Ingenol $\mathrm{R}=\mathrm{H}$



Triptolide $\mathrm{R}=\mathrm{H}$<smiles>CC(C)(C)C(=O)CCC(=O)CCC(=O)O</smiles><smiles></smiles>

Phenoxodiol

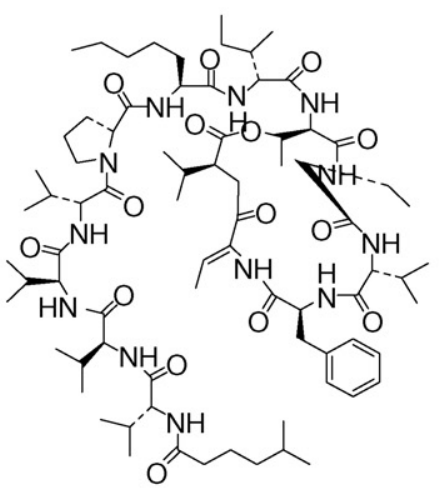<smiles>COc1cc(O)c2c(=O)oc(C(C)C(=O)O)cc2c1</smiles>

NM-3

\section{KahalalideF}


twigs of the tree Calophyllum lanigerum var. austrocoriaceum (Guttiferae). This compound was licensed to Sarwak Medichem Pharmaceuticals (SMP) and was being evaluated in combination with other anti-HIV agents. Calanolide A also has an activity against all Mycobacterium tuberculosis strains tested and may allow more efficient treatment of patients with both HIV and tuberculosis. The related coumarins calanolide B (costatolide), dihydrocalanolide $\mathrm{B}$ and oxocalanolide are also under preclinical development by Sarawak Medichem and NCI. The development of Calanolide A and its related compounds is on hold, and the fate will be decided by the Sarawak government, who now owns SMP and its HIV-therapeutic candidates [30,31].

Crofelemer (CAS 148465-45-6) in Phase III: It is an oligomeric proanthocyanidin derived from the latex of Croton lecheri (Euphorbiaceae) and being developed by Napo's partners, Trine Pharmaceuticals Inc. and AsiaPharm Group Ltd., to treat different types of diarrhoea. Crofelemer, is in various stages of clinical development for four distinct product indications, including (a) CRO-HIV for AIDS diarrhoea in Phase III, (b) CRO-IBS for diarrhoea irritable bowel syndrome ('D-IBS') and CRO-ID for acute infectious diarrhoea (including cholera) in Phase II and (c) CRO-PED for paediatric diarrhoea in Phase I. It has a novel anti-secretory mechanism of action that blocks chloride ion secretion via cystic fibrosis transmembrane conductance regulator (CFTR) channel, normalizes water flow in the gut treating diarrhoea and thereby preventing dehydration Recently, Napo obtained Special Protocol Assessment (SPA) agreement from U.S. FDA for Crofelemer in HIV/AIDS Diarrhea Assessment [http://www.prnewswire.com/, http:// www.napopharma.com].

DCK (PA-334B) in Phase I: It is a 3-hydroxymethyl-4-methyl khellactone coumarin derivative, a modified form of suksdorfin, which is isolated from methanol extracts of Lomatium suksdorfii (Apiaceae). DCK (PA-334B) is a nanomolar inhibitor of both primary clinical and drug resistant HIV-1 isolates. Panacos pharmaceutical has nearly completed the required preclinical studies for IND filing [31].

3,5-di-O-caffeoylquinic acid in Phase I: It was isolated from Inula britannica (Asteraceae). China's Academy of Military Sciences is carrying out clinical trial, which acts as an irreversible inhibitor of HIV and Hepatitis C integrase. It can be synthesized chemically and is also expected to be examined in combination with existing drugs for the above-mentioned two infections [32].

MX-3253 (celgosivir, MBI-3253, 6-O-butanoylcastanospermine) in Phase II: It is a semi-synthetic derivative of castanospermine, an alkaloid originally isolated from Castanospermum australe (Fabaceae). The Canadian company MIGENIX is evaluating it for the treatment of patients with chronic Hepatitis C. MX-3253 is an orally active inhibitor of $\alpha$-glucosidase I, a mammalian enzyme that affects the early stages of glycoprotein processing. Recently, the Phase II clinical trial as combination therapy with peginterferon $\alpha-2 b$ and ribavirin in Chronic Hepatitis C Genotype-1 Non-responder Patients has been completed [http://www.migenix.com/, http://www.hepatitis-central.com]. 4-Methylumbelliferone in Phase II: An umbelliferone (7-hydroxycoumarins) derivative present in many plants such as manna ash, sweet woodruff, German chamomile, celery, parsley, amongst others, is being developed for the treatment of
Hepatitis C and B by M T Medical Institute of Health, University of Texas Health Science Center at San Antonio and BioMonde Preparations Limited. Products containing 4-methylumbelliferone as their active substance have been available in the U.S.A. and Europe since 1990, as dietary supplements under the trade names Heparvit ${ }^{\circledR}$, Heparmed ${ }^{\mathbb{R}}$, DetoxPro ${ }^{\circledR}$ ) [http:// www.mtmedical.org/, http://www.clinicaltrial.gov/ct].

Milk Thistle in Phase II: The Silybum marianum (Asteraceae) has been used for centuries for diseases of the liver and biliary tract. A standardized extract of milk thistle (Silymarin) is being evaluated by the National Center for Complementary and Alternative Medicine (NCCAM). Silymarin has flavonoids silybinin, silydianin and silychristin as active constituents that work as antioxidants (scavenging free radicals) and inhibit lipid peroxidation. Studies also suggest that they protect against genomic injury, increase hepatocyte protein synthesis, decrease the activity of tumour promoters, stabilize mast cells, chelate iron and slow calcium metabolism [http://www.hepatitis-central.com/, http://www.clinicaltrials. gov/].

PA-457 (Bevirimat) in Phase IIb: It is 3-O-( $3^{\prime}, 3^{\prime}$-dimethylsuccinyl) betulinic acid, a semi-synthetic derivative of the plant triterpenoid betulinic acid isolated from the leaves of Syzygium claviflorum (Myrtaceae). Panacos Pharmaceutical is developing its lead compound PA-457 as an antiviral drug. The antiretroviral activity of PA- 457 is due to a novel mechanism of action, blocking a late step in processing of the Group-specific antigen (Gag) protein. The resulting virus particles are structurally defective and are incapable of spreading infection around the body. PA-457 is a new class of HIV drugs called maturation inhibitors [11,33]; http://www.panacos.com].

PYN6 in Phase I: This is a fraction isolated from a single plant and is being developed by Phynova as an antibacterial. In the preclinical screening assays conducted in China PYN6 has shown activity against major classes of infectious bacteria that have acquired resistance to current front-line antibiotics, such as methicilin-resistant Staphylococcus aureus (MRSA) [http:// www.phynova.com].

Sho-saiko-to (H09) in Phase II: It is a standardized aqueous extract from the roots of Scutellaria, Glycyrrhiza, Bupleurum and ginseng; the pinella tuber; the jujube fruit and the ginger rhizome. It is manufactured and supplied by Honso Pharmaceutical Co. Ltd. Japan and is under clinical studies to determine its effect on Hepatitis C patients. SST is known to have anti-fibrotic effect through inhibition of lipid peroxidation in hepatocytes and stellate cells in animal studies. It reduces aminotransferase levels, increases hepatic levels of superoxide dismutase and the incidence of hepatocellular carcinoma in hepatitis and liver cirrhosis patients [34]; [http://honsousa.com/Sho-saiko-to.htm, http://hepatitis-central.com].

Sutherlandia frutescens in Phase I: A shrub of the Fabaceae family was evaluated for its anti-HIV activity by the Medical Research Council of South Africa. The principal active constituents of $S$. frutescens include L-canavanine, GABA and D-pinitol. In vitro studies have shown effects of $S$. frutescens on CYP3A4, P-gp and PXR and produce nearly complete inhibition of CYP3A4 (96\%) [35]; [http://www.newscientist.com, http://www.clinicaltrials. gov]. 


\section{Pain and neurological disease applications}

In the modern world, neurological disorders, such as Alzheimer's disease, Parkinsonism, migraine, epilepsy, multiple sclerosis, and so on, are highly prevalent. It is estimated that in 2000 , mental and neurological disorders accounted for $12 \%$ of the total disabilityadjusted life years (DALYs) lost because of all diseases and injuries. By 2020, it is projected that the burden of these disorders will have increased by $15 \%$ [http://www.who.int/whr/2001/]. Some of the earliest drugs used for this category include opiate alkaloids from Papaver somniferum, tropane alkaloids like cocaine from Erythroxylon coca, galanthamine from Galanthus nivalis and the anticholinestrase agent physostigmine from Physostigma venenosum, and so on. The plant-derived drugs presently in clinical trials for this category are discussed below.

DA-5018 in Phase II: It is a synthetic capsaicin analogue that is being developed by the Korean company Dong-A Pharmaceuticals as a non-narcotic analgesic. Capsaicin causes the burning sensation associated with eating chillies by binding to the ion channel receptor transient receptor potential vanilloid (TRPV1) formerly vanilloid receptor subtype1 (VR1) [11]; [http:// www.donga-pharm.com/].

Dexanabinol in Phase III \& II: It is being developed by Pharmos as a neuroprotective product. Dexanabinol is a non-psychotropic dextrocannabinoid, currently undergoing Phase III clinical trials as a treatment for traumatic brain injury and Phase II testing as a preventative agent against post-surgical (CABG) cognitive impairment. Dexanabinol is an antioxidant, anti-inflammatory and a weak and safe $N$-methyl-D-aspartate receptor antagonist [http://www.rddirections.com, http://pharmalicensing.com/ article].

Ganstigmine (CHF2819) in Phase II: It is a novel AChE inhibitor derived from genserine, for which animal models suggest significant neuroprotection independent from its cholinergic activity. Chiesi Farmaceutici had been testing ganstigmine hydrochloride in Phase II for the treatment of AD; however, the company discontinued development of the drug candidate in order to focus resources on other therapeutic areas [http:// www.centerwatch.com, http://integrity.prous.com/].

IP-751 (Ajulemic acid, CT-3) in Phase II: It is a synthetic analogue of the THC metabolite, THC-11-oic acid developed by Atlantic Technology Ventures, U.S.A. and is currently at Indevus in Phase II clinical trials for the treatment of neuropathic pain. It is also undergoing clinical trials for treatment of tremor and spasticity in multiple sclerosis. IP-751 appears to inhibit COX-2 and other inflammatory cytokines, particularly interleukin- $1 \beta$, TNF- $\alpha$ and also the Peroxisomes Proliferating Activated Receptor- $\gamma($ PPAR- $\gamma$ ) and is partial cannabinoid (CB) receptor agonist [11,36]; [http://integrity.prous.com/].

LLL-2011 (Amigra) in Phase III: It is a botanical drug being developed by Lupin as a nasal spray for prophylaxis of migraine. Lupin has received regulatory approval in India to conduct clinical trials in 10 centres. In Phase II clinical trial it was found to be safe and well tolerated with good efficacy data [37]; [http://www.lupinworld.com/].

Lobeline in Phase I: It is a pyridine alkaloid isolated from Lobelia inflata (Campanulaceae), which has been used for centuries as an emetic and respiratory stimulant and, more recently, as a smoking cessation agent. Yaupon Therapeutics and NIH are evaluating Lobeline for methamphetamine addiction. Preclinical studies have suggested that lobeline has utility in helping to treat attention deficit hyperactivity disorder (ADHD) [11]; [http://www.yaupontherapeutics.com/].

M6G in Phase III: It is morphine 6-glucuronide a metabolite of morphine, the naturally occurring alkaloid in the opium poppy (Papaver somniferum). M6G is being developed by CeNeS Pharmaceuticals plc for post-operative pain following surgical procedure and has shown promising results comparable to morphine. It has superior side effect profile in terms of reduced liability to induce nausea, vomiting and respiratory depression. It has higher efficacy and low affinity on $\mu$-opioid receptor than morphine. The U.S. FDA has approved the IND application for the clinical development of M6G. CeNeS is currently completing the protocol design of the first U.S. Phase III trial [38]; [http://www.cenes.com/index.htm].

NGX-4010 in Phase III \& II: It is an application of a pure, highconcentration of synthetic trans-capsaicin developed by Neuroges $\mathrm{X}$ and is directly applied via a rapid-delivery dermal application system. Currently it is being studied in Phase III trials in post-herpetic neuralgia ( $\mathrm{PHN}$ ) and neuropathic pain related to HIV-associated neuropathy. Phase II trials are also underway for neuropathic pain related to peripheral diabetic neuropathy. The local anaesthetic effect results from continuous activation of the TRPV1 receptor, a ligand-gated ion channel activated by agonists such as capsaicin. NeurogesX plans to complete a confirmatory Phase III trial in PHN in the second half of 2007 [http://pharmalicensing.com, http:// www.neurogesx.com/ngx_4010].

P58 (PYM-50028, Cogane ${ }^{\mathrm{TM}}$ ) in Phase II: It is a plant-derived compound obtained from a traditional Asian 'tonic' that has been found beneficial to those with dementia. This novel nonpeptide is being developed by Phytopharm for the treatment of Parkinson's disease and AD type dementia. Cogane ${ }^{\mathrm{TM}}$ reverses the changes in area of the brain involved in Parkinson's disease by inducing the production of neurotrophic factors. These growth factors promote the growth and connectivity of neurones and reverse the atrophy of this area of the brain. In addition, this restores the learning and memory ability in Alzheimer's disease models and thereby offers the potential to reverse the symptoms of Alzheimer's disease [http:// www.phytopharm.co.uk, http://integrity.prous.com/].

Phenserine (Phenserine tartrate, Posiphen ${ }^{\mathrm{TM}}$ ) in Phase III/Phase I: It is a third generation derivative of phytostigmine isolated from Physostigma venenosum (Leguminosae) being developed by Axonyx to treat mild-to-moderate Alzheimer's disease (AD). It is a reversible acetylcholinestrase (AChE) inhibitor and also reduces the production of beta amyloid precursor protein $(\beta$ APP). Because of this dual mechanism of action, Phenserine has the potential to improve memory as well as to slow $A D$ progression. Posiphen is an antiamyloidogenic agent in Phase I clinical trials at TorreyPines for the treatment of $\mathrm{AD}$ and was recently acquired through a reverse merger with Axonyx [http:// www.centerwatch.com, http://integrity.prous.com/]; [11].

$R U 47213$ in Phase II: It is a pro-drug based on arecoline, an alkaloid found in Areca catechu L. (Palmae) under development for treatment of AD by Sanofi-aventis, whose carbamate function is hydrolyzed in vivo to form the tetrahydropyridine oxime $\mathrm{RU}$ 
35963, a muscarinic M1 agonist. After oral administration, RU 47213 seems superior to arecoline in terms of potency, central selectivity and duration of action, and is also active in animal models of cognition, without eliciting significant cholinergic side effects [39].

THC-CBD (Dronabinol/cannabidiol, GW-1000-02, Sativex ${ }^{\circledR}$ ) in Phase III: It is a cannabis (Cannabis sativa)-based pharmaceutical product containing delta 9-tetrahydrocannabinol (THC) and cannabidiol (CBD) in a 1:1 ratio and is being developed by GW Pharmaceuticals. It has been approved as adjunctive treatment for neuropathic pain and cancer pain with multiple sclerosis (MS) in U.K. and Canada. It is being investigated for the management of other MS symptoms, such as spasticity. They act on $\mathrm{CB}$ receptors that are involved in the control of spasticity where there is neurological damage. The most common adverse events (AEs) reported in trials were dizziness, sleepiness, fatigue, feeling of intoxication and a bad taste [http://www.gwpharm.com/, http://www.clinicaltrial.gov].

ZT-1 (DEBIO-9902) in Phase II: It is a pro-drug of huperzine isolated from the club moss, Huperzia serrata (Lycopodiaceae). ZT-1 was originally synthesized by Zhu and co-workers at Shanghai Institute of Material Medica. It is being evaluated by Debiopharm for the treatment of AD. The dual mode of action of ZT-1, as a $N$-methyl-D-aspartate receptor antagonist and an AChE inhibitor, positions it as a third generation antiAlzheimer's product by improving the general condition and cognitive functions of affected patients as well as having the potential of being a neuroprotectant [http://www.debiopharm. $\mathrm{com} / ;[11]$.

\section{Cardiovascular and metabolic disease applications}

Cardiovascular and metabolic diseases have been major causes of death throughout the world and are an ever increasing disease area because of the modern life style. According to the WHO cardiovascular diseases are the leading causes of death, responsible for $30 \%$ of all deaths or 17.5 million deaths in 2005 [25]. According to the International Diabetes Federation, 41 million people in India have diabetes, and this is expected to increase to 75-100 million people by 2025 . Thus, there is a need for new drugs in these categories in both the developed and developing worlds. Plant-based drugs have been a useful source of active compounds for these indications, including cardiac drugs like digoxin, sennosides, forskolin and $\alpha$ glucosidase inhibitors such as miglitol, for type 2 diabetes mellitus. Those drugs currently in clinical trials for these indications are reported below.

$P-57$ (P-57AS3) in Phase II: This is a functional food product candidate based on an extract of the succulent plant Hoodia gordonii (Asclepiadaceae), which has been traditionally eaten by Kung people of Kalahari desert to avoid feelings of hunger and thirst during hunting. P-57, a steroid glycoside, and related compounds were isolated from Hoodia gordonii by the South African Council for scientific and Industrial Research (CSIR). P-57 contains a novel satiety stimulator that reduces calorie intake in overweight subjects and, at present, is being developed by Phytopharm and Unilever for the oral treatment of obesity. [http://www.phytopharm.co.uk/].

PMI-5011 in Phase II: This is a proprietary anti-diabetic botanical extract derived from Artemisia dracunculus L. It is currently going through human efficacy study in 30 patients with type 2 diabetes. The synergistically acting compounds in the extract are likely to be responsible for its pronounced anti-diabetic effects that include modulation of aldose reductase inhibitors, steroid $5 \alpha$-reductase inhibitors, xanthine oxidase inhibitors, glucagon like peptide-1 (GLP-1) binding, increase in glucose muscle uptake and inhibition of phosphoenolpyruvate carboxykinase (PEPCK) activity [http://www.phytomedics.com/].

\section{Inflammatory and related disease applications}

Plant-based drugs and many herbal preparations alter immune function and have an amazing array of immunomodulatory effects attributed to them [40]. The salicyclic acid derivative, aspirin, has been a cornerstone for the treatment of inflammation-associated diseases, and many plant-based preparations have also been reported for their activity against immunological conditions [41].

Flavocoxid in Phase I: An extract derived from Scutellaria baicalensis (Lamiaceae) and Acacia catechu (Mimosaceae) is being developed for Osteoarthritis by National Institute of Arthritis and Musculoskeletal and Skin Diseases (NIAMS), U.S.A. and Primus Pharmaceuticals. It has been shown to inhibit cyclooxygenase (COX)-1 and COX-2 as well as 5-lipooxygenase [http:// www.clinicaltrial.gov].

Grazax in Phase III: The standardized extract of the protein allergens obtained from the pollen of Phleum pretense (Poaceae) is being developed by ALK-Abelló (Sweden) for hay fever. It has been launched in Germany, Denmark, Norway, Sweden and the U.K. Clinical trials have shown that during the first allergy season, Grazax can reduce hay fever symptoms by $30 \%$ and reduce the need for symptomatic medication. Side effects include tingling or itching in the mouth. Phase III clinical trials are underway for use in the treatment of children aged 516 years with grass pollen induced rhinoconjunctivitis with or without asthma [42]; [http://www.alk-abello.com/].

Paxceed (micella Paclitaxel) in Phase II: An intravenous chemotherapy agent with anti-inflammatory and immunomodulatory properties is being developed by Angiotech Pharmaceuticals for RA. The active substance in Paxceed ${ }^{\mathrm{TM}}$, paclitaxel, has demonstrated its usefulness as an agent that stops growth of cells and blocks certain types of cell function associated with RA. Because of these effects, it is thought that Paxceed $^{\mathrm{TM}}$ might alter the destructive course of RA. Another advantage is synergism rather than competition with recently developed anti-TNF therapies [http://www.centerwatch.com/, http://www.clinicaltrials.gov/, http://www. angiotech.com/].

PMI-001 in Phase III: An orally bioavailable and multimechanism botanical drug for auto-immune disease exerts its potent anti-inflammatory/immunosuppressant activities through unique and synergistic modes of action, including inhibition of IL-2, a-TNF, i-NOS, and COX-2 gene transcription. The Phase II trial showed halting joint erosion and joint space narrowing, and evidence of extremely rapid pain and inflammation reduction [http://www.phytomedics.com/].

PMI-005 Phase II completed: It is an anti-inflammatory botanical drug candidate being developed by Phytomedics for rheumatoid arthritis. PMI-005 is an orally bioavailable, small molecule gene-transcription inhibitor of a variety of pro- 
TABLE 2

\section{Plant-based anticancer drugs in clinical trials}

Name of analogue Clinical status Developer Refence

(A) Paclitaxel/Taxol analogues; MOA a -antimiotic agent blocking cells in the metaphase [48]

\begin{tabular}{llll}
\hline ABI-007 (suspension) & Phase III & American Biosciences & [49], http://www.abraxisbio.com/ \\
\hline BMS-188797 & Phase II & Bristol-Myers Squibb & [http://www.bms.com/] \\
\hline BMS-184476 & Phase II & Bristol-Myers Squibb & [http://www.bms.com/] \\
\hline BMS-275183 & Phase I/II & Bristol-Myers Squibb & [http://www.bms.com/] \\
\hline DHA-paclitaxel & Phase III & Luitpold & [http://www.luitpold.com] \\
\hline DJ-927 & Phase II & Daiichi-Sankyo & [http://www.sankyopharma.com/ \\
& & & products/pipeline.html] \\
\hline MAC-321 (TL-00139) & Phase II & Wyeth/Taxolog & [http://www.wyeth.com,www.taxolog.com] \\
\hline MST-997 (TL-909) & Phase I & Wyeth/Taxolog & [http://www.wyeth.com,www.taxolog.com] \\
\hline Ortataxel (IDN-5109, BAY-59-8862) & Phase II & Bayer/Indena & [11] \\
\hline Paclitaxel poliglumex (Xyotav) & Phase III & Cell Therapeutics & [50], http://www.cticseattle.com/ \\
\hline PNU-166945 (Taxol-HMPA polymer) & Phase I & Pfizer & [49], http://www.pfizer.com/ \\
\hline RPR-116258A & Phase III & Sanofi-Aventis & [http://www.sanofi-aventis.com] \\
\hline TPI-287 & Phase II & Tapestry Pharmaceuticals & [51], http://www.tapestrypharma.com/ \\
\hline TXD-258 (XRP-6258, RPR-116258A) & Phase Ila & Sanofi-Aventis & [http://www.sanofi-aventis.com] \\
\hline XRP_9881 (RPR-109881 A) & Phase III & Sanofi-Aventis & [11,49] \\
\hline
\end{tabular}

(B) Camptothecin-based analogues; $\mathrm{MOA}^{\mathrm{a}}$ - topoisomerase I inhibitor [52]

\begin{tabular}{llll}
\hline 9-amino camptothecin & Phase III & Pharmacia & [49] \\
\hline BN-80927 & Phase I & Ispen/Roche & [http://www.ipsen.com, http://www.roche.com] \\
\hline Diflomotecan (BN-80915) $\mathbf{1 0 0}$ & Phase II & Ipsen & [http://www.ipsen.com] \\
\hline DRF-1042 & Phase II & Dr Reddy & [http://www.drreddys.com] \\
\hline Exatecan mesilate & Phase III & Daiichi Pharmaceuticals & [49], http://www.daiichipharm.co.jp/english/ \\
\hline Gimatecan (ST-1481) & Phase II & Novartis/Sigma-Tau & [11] \\
\hline Irinotecan (Hycamp) & Phase IIb & Meditech's \& Alchemia & [53] \\
\hline Karenitecin ${ }^{\circledR}$ (BNP-1350) & Phase I/II & BioNumerik & [11] \\
\hline LE-SN38 & Phase I/II & Neo Pharm & [http://www.neopharm.com] \\
\hline Lurtotecan & Phase II & Glaxo/Gilead science & [49] \\
\hline NK012 (nanoparticle formulation) & Phase II & Nippon Kayaku & [54] \\
\hline Oral topotecan (Hycamptin) & Phase III & GlaxoSmithKline & [55] \\
\hline PG-Camptothecin & Phase II & Cell Therapeutics & [49], http://www.cticseattle.com/ \\
\hline Rubitecan (9-nitro camptothecin) & Phase III & SuperGen & [56] \\
\hline Sphigosomal topotecan & To be launched in 2007 & Inex pharmaceuticals & [57] \\
\hline
\end{tabular}

(C) Combrestatin analogues; $\mathrm{MOA}^{\mathrm{a}}$-inhibitor of colchicine binding site [58]

\begin{tabular}{llll}
\hline AVE-8062 (AC-7700) & Phase I & Sanofi-Aventis & {$[45]$} \\
\hline AVE-8064 & Phase I & Sanofis-Aventis & {$[49]$} \\
\hline AVE-8063 & Phase I & Sanofis-Aventis & {$[49]$} \\
\hline CA4PO $_{4}$ (combrestatin A-4 phosphate) & Phase II & OXiGENE & {$[45]$}
\end{tabular}

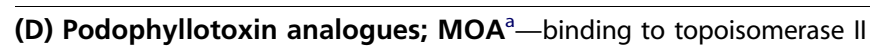

\begin{tabular}{llll} 
NK-611 & Phase I & Nippon Kayaku & http://www.nipponkayaku.co.jp/english \\
\hline Tafluposide $\mathbf{1 0 5}$ & Phase I & Pierre Fabre & [11]
\end{tabular}

(E) Vinca alkaloids analogues; MOA $^{\mathrm{a}}$-microtubule destabilising agents and bind to tubulin heterodimers [59-61]

\begin{tabular}{|c|c|c|c|}
\hline Anhydrovinblastine (Hydravin ${ }^{\mathrm{TM}}$ ) & Phase II & Keryx & [11] \\
\hline Venorelbine & Phase III & Novacea & {$[62]$} \\
\hline $\begin{array}{l}\text { Vincristine sulfate TCS } \\
\text { (OncoTCS)/Marqibo }\end{array}$ & Phase III & $\begin{array}{l}\text { Enzon Pharmaceuticals/Inex } \\
\text { Pharmaceuticals/Hanna Biosciences }\end{array}$ & {$[55]$} \\
\hline Vinflunine ditartrate $\left(\right.$ Javlor $^{(\mathbb{B})}$ & Phase III & Pierre Fabre/Bristol-Myers Squibb & {$[11]$} \\
\hline
\end{tabular}

${ }^{\mathrm{a}} \mathrm{MOA}$, mechanism of action. 
TABLE 3

Other plant-based anticancer drugs in clinical trials

\begin{tabular}{|c|c|c|c|c|c|}
\hline Name & Lead compound/plant & MOA $^{a}$ & Clinical status & Developer & Reference \\
\hline Bruceantin & Brucea antidysenterica & $\begin{array}{l}\text { Inhibit peptidyl transferase } \\
\text { elongation reaction }\end{array}$ & Phase II & $\mathrm{NCl}^{\mathrm{b}}$ & $\begin{array}{l}\text { [63], http://www.cancer.gov/ } \\
\text { search/resultsclinicaltrials }\end{array}$ \\
\hline $\begin{array}{l}\text { Dimethyl xanthene- } \\
\text { 9-one-4-acetic acid (DMXAA) }\end{array}$ & Flavone-8-acetic acid analogue & TNF- $\alpha$ induction & Phase II & Antisoma & [64], http://www.antisoma.co.uk/ \\
\hline Flavopiridol & $\begin{array}{l}\text { Flavone based/Amoora rohituka \& } \\
\text { Dysoxylum binecteriferum }\end{array}$ & $\begin{array}{l}\text { Interfering with CDK and there } \\
\text { by blocking cell cycle progression }\end{array}$ & Phase III & Sanofi-Aventis, $\mathrm{NCl}^{\mathrm{b}}$ & [65], http://www.sanofi-aventis.com/ \\
\hline $\begin{array}{l}\text { Homoharringtone } \\
\left.\text { (Ceflatonin }{ }^{\circledR}\right)\end{array}$ & $\begin{array}{l}\text { Homoharrington/Cephalotaxus } \\
\text { harringtonia }\end{array}$ & Protein synthesis inhibition & Phase II & ChemGenex & [63], http://www.chemgenex.com \\
\hline Ingenyl 3-angelate (PEP005) & Ingenol & Protien kinase $\mathrm{C}$ activation & Phase Ila & Peplin & [11], http://www.peplin.com \\
\hline 4-Ipomeanol & Furan derivative/lpomoea batatas & DNA binding & Phase II & $\mathrm{NCl}^{\mathrm{b}}$ & [63], http://www.cancer.gov/ \\
\hline Kahalalide F & Alga (Bryopsis sp.)/Sea slug & Interferes with lysosome function & Phase I & PharmaMar & [66] \\
\hline Kanglaite & Coix lachryma-jobi & $\begin{array}{l}\text { Inhibits mitosis of tumour cells during } \\
\mathrm{G} 2 / \mathrm{M} \text { phase }\end{array}$ & Phase II & $\begin{array}{l}\text { Zhejiam kanglaite } \\
\text { pharmceutical }\end{array}$ & [39] \\
\hline Meisoindigo & $\begin{array}{l}\text { Indirubin derivative/Indigofera } \\
\text { tinctoria }\end{array}$ & Apoptosis by blocking Stat3 signaling & Phase III & $\begin{array}{l}\text { Chinese Academy of } \\
\text { Sciences }\end{array}$ & [67] \\
\hline NM-3 & Isocoumarin derivative & $\begin{array}{l}\text { Inhibits VEGF expression, } \\
\text { angiogenesis inhibitor }\end{array}$ & Phase I complete & ILEX oncology & [68] \\
\hline Perillyl alcohol & Limonene analogue & Activate capase 3 , apoptosis & Phase II completed & $\mathrm{NCl}^{\mathrm{b}}$ & http://www.cancer.gov/ltrials \\
\hline PG490-88Na & Triptolide & $\begin{array}{l}\text { T cell proliferation suppression, IL-2 } \\
\text { expression \& NFk-B activation }\end{array}$ & Phase I & Pharmagenesis & [http://integrity.prous.com/] \\
\hline Phenoxodiol & Daidzein & NADH oxidase (tNOX) inhibition & Phase III/Phase I & Marshall Edwards/Novogen & $\begin{array}{l}\text { http://www.cancer.gov/ } \\
\text { search/resultsclinicaltrial }\end{array}$ \\
\hline $\begin{array}{l}\text { Protopanaxadiol } \\
\text { (PBD-2131, Pandimex }{ }^{\mathrm{TM}} \text { ) }\end{array}$ & Protopanaxadiol & Caspase 3, 8 \& 9 stimulant & Phase I & PanaGin & http://www.panagin.com \\
\hline Roscovitine (CYC 202) & Olomucine/Raphanus sativus & CDK inhibitor & Phase II & Cyclacel & http://www.cyclacel.com \\
\hline SAOB-0401 (Xenavex ${ }^{\mathrm{TM}}$ ) & Oleandrin/Nerium oleander & $\begin{array}{l}\text { Inhibit fibroblast growth factor-2 (FGF-2), } \\
\text { blocked tumour necrosis factor (TNF) } \\
\text { induced NF-kB activation }\end{array}$ & Phase $1 / I I$ & $\begin{array}{l}\text { Shimoda-atlantic Oncology } \\
\text { Biosciences }\end{array}$ & http://www.clinicaltrial.gov \\
\hline
\end{tabular}

${ }^{a} \mathrm{MOA}$, mechanism of action.

${ }^{\mathrm{b}} \mathrm{NCl}$, National Cancer Institute. 
inflammatory cytokines including a-TNF, i-NOS, IL-1 beta and COX-2 [http://www.phytomedics.com/].

PYN17 in Phase IIa: A formulation of 1 European and 3 Chinese plants, which individually have been used to treat liver diseases in Asia and Europe, is being developed by Phynova as a treatment for the symptoms of Chronic Hepatitis C (CHC). PYN17 exhibited a range of pharmacological activities, including immuno-modulation, hepato-protection, and anti-inflammation. Clinical trials suggest that PYN17 could be developed both as a stand alone treatment and an adjunct treatment alongside established drugs for viral hepatitis, and other inflammatory liver diseases such as alcoholic cirrhosis and fatty livers associated with metabolic disorders [http://www.phynova.com/].

QS-21A and QS-21B in Phase II and III: The saponins derived from the South American tree, Quillaja saponaria (Rosaceae), have shown great promise as investigational adjuvants and are added to vaccines and other immunotherapies designed to enhance the body's immune response to the antigen contained within the treatment. QS-21 is an integral part of experimental vaccines being evaluated in Phase II and III trials for melanoma, malaria, HIV and other infectious diseases [11]; [http:// www.clinicaltrials.gov/].

\section{Oncological disease applications}

Cancer is a complex disease that involves uncontrolled multiplication and spread (metastasis) of abnormal form of body's own cells. As per WHO 13\% of world deaths, that is, about 7.6 million deaths accounted in 2005 are because of cancer, and this percentage is expected to increase in coming years [25]. Plantderived compounds have played an important role in treatment of cancers, and some of the most promising and better drugs have come up from plant sources like Taxol ${ }^{\mathbb{R}}$ [43], Camptothecin
[44], Combrestatin [45], Epipodophyllotoxin [46] and Vinca alkaloids (vinblastine, vincristine [47]. These drugs have also been the major source of new drug candidates for the treatment of cancers. Apart from this many other plant-derived compounds that are in clinical trials for cancers are tabulated in Tables 2 and 3 .

\section{Conclusion and future perspectives}

The resurgence of plant-based drugs, as evident by the number of drugs in clinical trials, mainly for the treatment of cancer, immunological and CNS related diseases, is certainly exciting. There are many new plant-based drug candidates in active preclinical trials like Prostratin, CAPSOROLS and CCS. Inputs from traditional medical knowledge and using modern techniques to speed up the plant-based drug discovery have now made us to think beyond the only $10-15 \%$ of plant diversity that have been explored for their pharmaceutical purpose so far. Plants, the best combinatorial chemists, still wait for us to discover the hitherto hidden secrets of their healing properties to unburden mankind from dreaded diseases. Over 60 compounds are in the pipeline, as anticancer drugs alone, from plant sources. This is expected to remain an interesting disease area in the future as well. We must equip ourselves to screen a sizeable number of plants from our .27 million plant species, which can only be achieved by the concerted efforts exemplified by the NCI in recent years.

\section{Acknowledgements}

We are thankful to the Director, National Institute of Pharmaceutical Education and Research (NIPER) for facilities and to the companies who continue to put in their resources for the development of natural products.

\section{References}

1 Solecki, R.S. (1975) Shanidar IV, a Neanderthal flower burial in northern Iraq. Science 190, 880-881

2 Raskin, I. and Ripoll, C. (2004) Can an apple a day keep the doctor away? Curr. Pharm. Des. 10, 3419-3429

3 Fabricant, D.S. and Farnsworth, N.R. (2001) The Value of plants used in traditional medicine for drug discovery. Environ. Health Perspect. 109 (Suppl 1), 69-75

4 Clardy, J. and Walsh, C. (2004) Lessons from natural molecules. Nature 432, 829-837

5 Corcoran, O. and Spraul, M. (2003) LC-NMR-MS in drug discovery. Drug Discov. Today 8, 624-631

6 Steinbeck, C. (2004) Recent development in automated structure elucidation of natural products. Nat. Prod. Rep. 21, 512-518

7 Ganesan, A. (2002) Recent developments in combinatorial organic synthesis. Drug Discov. Today 7, 47-55

8 Cardellina, J.H. (2002) Challenges and opportunities confronting the botanical dietary supplement industry. J. Nat. Prod. 65, 1073-1084

9 Raskin, I. et al. (2002) Plants and human health in the twenty-first century. Trends Biotechnol. 20, 522-531

10 Butler, M.S. (2004) The role of natural product chemistry in drug discovery. J. Nat. Prod. 67, 2141-2153

11 Butler, M.S. (2005) Natural products to drugs: natural product derived compounds in clinical trials. Nat. Prod. Rep. 22, 162-195

12 Newman, D.J. and Cragg, G.M. (2004) Marine natural products and related compounds in clinical and advanced preclinical trials. J. Nat. Prod. 67, 1216-1238

13 Haefner, B. (2003) Drugs from deep: marine natural products as drug candidates. Drug Discov. Today 8, 536-544

14 Chin, Y.W. et al. (2006) Drug discovery from natural sources. AAPS J. 8, E239-E253 15 McWilliams, A. (2006) Plant-Derived Drugs: Products, Technology, Applications (BIO022D) BBC Research (http://www.bbcresearch.com)

16 McWilliams, A. (2003) B-121N Plant-Derived Drugs: Products, Technology, Applications BBC, Research (http://www.bbcresearch.com)

17 Major new product approvals in the US market in 2000. Scrip Mag. 78, 78

18 Southgate, J. (2001) A bumper year for launches bucks the downward trend. Scrip Mag. 78, 80-81

19 Lloyd, I. (2003) A little jam today, but more tomorrow? Scrip Mag. 120, 60-61

20 (2003) Major new EU product approvals. Scrip Mag. 120, February 2003, 59 (http://www.scripmag.com/)

21 (2004) Major new US product approvals. Scrip Mag. 131, February 2004, 45 (http://www.scripmag.com/)

22 Lloyd, I. (2004) The R\&D revolution remains elusive. Scrip Mag. 131, 52-53

23 Lloyd, I. (2005) Does lack of launches spell end of expansion. Scrip Mag. 142 24-25

24 (2006) 2005 New drugs tally shows pharma could try harder. Scrip World Pharmaceutical News 3136, March 3, 21

25 (2006) World health statistics 2006. pp. 1-80, WHO (http://www.who.int/)

26 Cowan, M.M. (1999) Plant products as antimicrobial agents. Clin. Microbiol. Rev. 12 , 564-582

27 Perfect, M.M. et al. (2005) Use of complementary and alternative medicine for the treatment of genital herpes. HERPES 12, 38-41

28 Gibbons, S. (2004) Anti-staphylococcal plant products. Nat. Prod. Rep. 21, 263-277

29 Robert, A. et al. (2001) From classical antimalarial drugs to new compounds based on the mechanism of action of artemisinin. Pure Appl. Chem. 73, 1173-1188 
30 Kashman, Y. et al. (1992) The calanolides, a novel HIV-inhibitory class of coumarin derivatives from the tropical rainforest tree Calophyllum lanigerum. J. Med. Chem. 35, 2735-2743

$31 \mathrm{Yu}$, D. et al. (2003) Recent progress in the development of coumarin derivatives as potent anti-HIV agents. Med. Res. Rev. 23, 322-345

32 (2006) Scrip World Pharmaceutical News 3137, 18

33 Li, F. et al. (2003) PA-457: a potent HIV inhibitor that disrupts core condensation by targeting a late step in Gag processing. Proc. Natl. Acad. Sci. U. S. A. 100, 135513560

34 Schuppan, D. et al. (1999) Herbal products for liver diseases: a therapeutic challenge for the new millennium. Hepatology 30, 1099-1104

35 Mills, E. et al. (2005) African herbal medicines in the treatment of HIV: Hypoxis and Sutherlandia. An overview of evidence and pharmacology. Nutr. J. 4, 19. doi:10.1186/1475-2891-4-19 In: http://www.nutritionj.com

36 Whelan, J. (2002) New cannabinoid for multiple sclerosis. Drug Discov. Today 7, 745 746

37 (2006) Scrip World Pharmaceutical News 3220, 25

38 Kilpatrick, G.J. and Smith, T.W. (2005) Morphine-6-glucuronide: actions and mechanism. Med. Res. Rev. 25, 521-544

39 Camps, P. and Muñoz-Torrero, D. (2002) Cholinergic drugs in pharmacotherapy of Alzheimer's disease. Mini Rev. Med. Chem. 2, 11-25

40 Plaeger, S.F. (2003) Clinical immunology and traditional herbal medicines. Clin. Diag. Lab. Immunol. 10, 337-338

41 Patwardhan, B. and Gautam, M. (2005) Botanical immunodrugs: scope and opportunities. Drug Discov. Today 10, 495-502

42 (2006) Scrip World Pharmaceutical News 3140, 19, in press

43 Wani, M.C. et al. (1971) Plant antitumor agents. VI. The isolation and structure of Taxol, a novel antileukemic and antitumor agent from Taxus brevifolia. J. Am. Chem. Soc. 93, 2325-2327

44 Wall, M.E. (1998) Camptothecin and Taxol: discovery to clinic. Med. Res. Rev. 18, 299-314

45 Cirla, A. and Mann, J. (2003) Combrestatins: from natural product to drug discovery. Nat. Prod. Rep. 20, 558-564

46 Canel, C. et al. (2000) Podophyllotoxin. Phytochemistry 54, 115-120

47 Johnson, I.S. et al. (1963) The Vinca alkaloids: a new class of oncolytic agents. Cancer Res. 23, 1390

48 Lataste, H. et al. (1984) Relationships between the structures of Taxol and baccatine III derivatives and their in vitro action on the disassembly of mammalian brain and
Physarum amoebal microtubules. Proc. Natl. Acad. Sci. U. S. A 81, 4090-4094

49 Cragg, G.M. and Newman, D.J. (2004) A tale of two targets: Topoisomerase I and tubulin The Wall and Wani contribution to cancer chemotherapy. J. Nat. Prod. 67, 232-244

50 Singer, J.W. et al. (2005) Paclitaxel poliglumex (XYOTAX; CT-203): an intracellularly targeted taxane. AntiCancer Drugs 16, 243-254

51 (2006) Scrip World Pharmaceutical News 3136, 11, in press

52 Giovanella, B.C. et al. (1989) DNA topoisomerase I-targeted chemotherapy of human colon cancer in xenografts. Science 246, 1046-1048

53 (2006) Scrip World Pharmaceutical News 3140, 12, in press

54 (2006) Scrip World Pharmaceutical News 3121, 15

55 Peters, B. (2007) New cancer therapies for 2007-looking to the future. Oncol. Issues 34-39

56 (2004) Rubitecan: 9-NC, 9-Nitro-20(S)-Camptothecin, 9-Nitro-Camptothecin, 9-Nitrocamptothecin, RFS 2000, RFS2000. Drugs in R \& D. 5, 305-311

57 (2006) Scrip World Pharmaceutical News 3142, 13

58 Jordan, A. et al. (1998) Tubulin as a target for anticancer drugs: agents which interact with the mitotic spindle. Med. Res. Rev. 18, 259-296

59 Jordan, M.A. et al. (1986) Identification of a distinct class of vinblastine binding sites on microtubules. J. Mol. Biol. 187, 61-73

60 Erickson, H.P. (1975) Negatively stained vinblastine aggregates. Ann. N.Y Acad. Sci. 253, 51-52

$61 \mathrm{Na}$, G.C. and Timasheff, S.N. (1982) In vitro vinblastine-induced tubulin paracrystals. J. Biol. Chem. 257, 10387-10391

62 (2006) Scrip World Pharmaceutical News 3158, 7

63 da Rocha, A.B. et al. (2001) Natural products in anticancer therapy. Curr. Opin. Pharmacol. 1, 364-369

64 Westwell, A.D. (2003) Novel Antitumour molecules. Drug Discov. Today 8, 47-50

65 Newcomb, E.W. (2004) Flavopiridol: pleiotropic biological effects enhance its anticancer activity. AntiCancer Drugs 15, 411-419

66 Hamann, M.T. et al. (1996) Kahalalides: bioactive peptides from a marine mollusk Elysia rufescens and its algal diet Bryopsis sp. J. Org. Chem. 61, 6594-6600

67 Bradbury, J. (2005) From Chinese medicine to anticancer drug. Drug Discov. Today $10,1131-1132$

68 Quesada, A.R. et al. (2006) Anti-angiogenic drugs: from bench to clinical trials. Med. Res. Rev. 26, 483-530 